LAW, ETHICS, AND MEDICINE

\title{
Individual and family consent to organ and tissue donation: is the current position coherent?
}

T M Wilkinson

J Med Ethics 2005;31:587-590. doi: 10.1136/jme.2004.009654

Correspondence to: T M Wilkinson, School of Population Health University of Auckland, Private Bag 92019, Auckland, New Zealand; m.wilkinson@ auckland.ac.nz

Received 2 June 2004 In revised form 23 September 2004 Accepted for publication 4 December 2004

\begin{abstract}
The current position on the deceased's consent and the family's consent to organ and tissue donation from the dead is a double veto-each has the power to withhold and override the other's desire to donate. This paper raises, and to some extent answers, questions about the coherence of the double veto. It can be coherently defended in two ways: if it has the best effects and if the deceased has only negative rights of veto. Whether the double veto has better effects than other policies requires empirical investigation, which is not undertaken here. As for rights, the paper shows that it is entirely possible that individuals have a negative right of veto but no positive right to compel acceptance of their offers. Thus if intensivists and transplant teams turn down the deceased's offer, they do not thereby violate the deceased's right. This leaves it open whether non-rights based reasons - such as avoiding bad publicity or distress - require intensivists and transplant teams to turn down or accept the deceased's offer. This, however, is beyond the scope of this paper. The current position may or may not be wrong, but it is at least coherent.
\end{abstract}

$\mathrm{T}$ he UK and New Zealand are currently reviewing the arrangements for the procurement of tissues and organs. One of the questions raised, in the case of dead people, is who should have the ultimate power to donate or withhold tissue and organs in cases where the individual and the family disagree with each other. On the assumption that it must be one or the other, there are four serious answers: (1) that the individual's wishes should be decisive, whether to donate or withhold; (2) that the family's wishes should be decisive, whether to donate or withhold; (3) that the individual's wish to donate should override the family's refusal, and the family's wish to donate should override the individual's refusal, and (4) that the individual's refusal should override the family's wish to donate, while the family's refusal should override the individual's wish to donate. This last view is the current position in the UK and New Zealand. It is the subject of this paper, which is a philosophical contribution to the ethics of organ donation.

As things stand, the law does not permit acquiring organs and tissues from the bodies of people who are known to have objected, even if their families wish to donate. The law gives individuals a veto on the use of their bodies. Medical practice is to refuse to retrieve organs and tissues from dead bodies without the consent of the families, even if the individual had wanted to donate. Medical practice gives families a veto on the use of the bodies. These claims about the law and practice are relatively uncontroversial. If, in practice, the family's wish to donate overrides the objections of the individual, that is neither a legal requirement nor state policy. ${ }^{1-3}$ This position, which might be called "the double veto", is supported by many involved in both donation and transplantation.

Considering it is the current position, it is rather surprising that it is hard to find a detailed defence of the double veto. Indeed there are only a few discussions of the ethics of the role of the family at all. ${ }^{4}$ To be sure, there are arguments for the individual having a veto and for the family having a veto, but rarely for both having a veto. Simply adding the arguments for the individual veto to those for the family veto is unlikely to work. As will shortly be shown, arguments for the one tend to undercut, not complement, the arguments for the other. The worry is that there is no coherent case for the double veto, just a mish mash of different and conflicting views. If no coherent case can be made, then we can hardly have confidence that the current position is right. If, on the other hand, a coherent case can be made, while this does not guarantee it is right, it is a step toward thinking it is.

This paper sketches two coherent cases for the current position. Since, as mentioned, a coherent case for the current position is rarely, if ever, made, this is achievement enough for a short paper. It is just not possible to give a full account here of the right role for individuals and the family in donation, which would be a large task-probably larger than most realise. It would require, among many other things, defending a position on the status of the wishes of the dead, which would in turn require discussing the possibility of posthumous interests and rights, which is a highly controverted philosophical topic. ${ }^{67}$

Some more scene setting. First, the paper considers only those cases where individuals and their families are known to disagree. It ignores cases where the wishes of individuals or families are unknown; where family members disagree among themselves and it cannot be said that there is a single family view; and where the individual wants the family to make the ultimate decision, or vice versa. Second, it ignores the background scarcity of organs and tissues in order to focus only on the individual and the family. Third, various terms such as "retrieval", "veto", "individual", and "donation" are intended to be neutral and to presuppose nothing about the ethically correct methods of organ and tissue procurement.

\section{WHAT REALLY FOLLOWS FROM THE ARGUMENTS?}

The problem is not that it is inconsistent to assign both individual and family a veto on retrieval, since it is not. The problem is that the arguments for giving the one a veto tend to undercut giving the other a veto. Let us consider some examples. The focus is on arguments made on behalf of the family veto. Some support the family veto directly and others criticise the opposing position that individuals alone should decide. 


\section{Distress}

Perhaps the most frequently cited reason for giving the family decision making authority is to do with the distress family members suffer at a tremendously difficult time. ${ }^{8}$ Very many of those who are suitable organ and tissue donors die suddenly and prematurely. The decision about whether to donate has to be made quickly, and families might well find that they cannot agree to donate. If their wishes not to donate are overridden, even if in accordance with the wish of the deceased to donate, this might well increase the distress the families are already feeling. Obviously there is good reason not to increase distress.

The aim here is not to assess whether the appeal to distress offers a good reason for the family veto. The point is that any reason would not stop with the family veto. It is possible that a family would be distressed if it were unable to donate the organs because of the deceased's refusal. The family might have firm views about the importance of not wasting the means to someone else's life. It might want something good to come of their relative's premature death. In so far as the goal is to reduce the distress of the family, or avoid causing more, distress cuts both ways. It can support not just a veto but also giving the family the power to donate against the wishes of the deceased.

\section{The insignificance of the consent of the deceased}

Many lay people are appalled to discover that their wishes to donate are not binding. They often believe that people who have signed a donor card or ticked the donor box on their driving licence have consented to donate, and that this consent should be binding. Some claim, though, against this position and on behalf of the family veto, that individual consent is being overrated in this argument. There are more and less dramatic forms of this argument. The more dramatic claim is that the dead cannot consent. This is tautologically true. If consenting requires being able to do something, and the dead cannot do anything, the dead cannot consent. This tautology is not, however, in and of itself, a reason against respecting wishes expressed before death. The claim might be that predeath wishes do not matter much because, once deceased, the individual's welfare cannot be affected, or not greatly affected, by decisions about the use of her body-and that is a dramatic claim because it takes a stand on the question of posthumous interests, which is, as mentioned, very controversial. The less dramatic claim points out that signing a card or ticking a box on a form to get a driving licence does not meet adequate standards of informed consent, and that the ticking might have taken place years before death. ${ }^{10}$ What follows is not clear, but it might be said that, if we think retrieval none the less permissible despite the absence of proper individual informed consent, that shows we do not really think individual consent important in these cases.

Never mind whether the various arguments for disregarding the individual's desire to donate are good ones. The point is that, again, they do not support the current position, which gives the individual a veto. All the arguments just outlined support removing the individual's right to veto the use of her or his body.

\section{Cultural sensitivity}

The New Zealand Ministry of Health review points out that New Zealand is culturally diverse and that different groups will have different responses to organ and tissue donation, although, characteristically for government documents, it fails to draw any substantive conclusions from these claims. ${ }^{11}$ Still, it might be said-and is in other contexts $^{12}$ - that not all cultures are as individualistic or materialistic as the mainstream Western tradition, that in some cultures, individual's wishes do not override the family's, and that it would be inappropriately culturally insensitive to insist that they do. (Boddington, ${ }^{9}$ pp 77-9). One might observe that it is unclear how individualistic or materialistic Western culture is in the matter of organ and tissue donation, since it is commonplace to allow the family to override the individual. Anyway, ignoring the many faults in this argument, as before, it does not support the current position. Suppose that being sensitive to cultural views about donation requires doing what those views say. If some cultures hold, either explicitly or by inference from their other beliefs, that families who wished to donate were able to override the wishes of the individual, it would follow from being culturally sensitive that individuals would not have a right to veto the use of their bodies.

\section{GOOD EFFECTS AND NEGATIVE RIGHTS: TWO WAYS TO PRODUCE A COHERENT POSITION}

The point of the discussion so far is that the current position of the double veto cannot be justified on the basis of the usual arguments on behalf of the family's power to veto an individual's wish to donate. Those arguments imply that the family should have the power both to withhold and to donate the bodies of their deceased relatives against those relatives' wishes, whereas the current position is to give the deceased a veto. The arguments for an individual veto also tend not to support the current position because they undercut the family veto-as those who support the individual veto often intend. Some argue, for example, that individuals should have the power to control their bodies after their deaths because this is an important part of being autonomous. This argument supports, and is usually intended to support, the power both to veto donation and to veto the family's objection to donation.

At this stage, then, the current position looks like an incoherent hybrid. The rest of this paper, however, describes the two most promising ways to produce a coherent defence of the double veto, as well as some of the difficulties that face each. The first claims that the double veto has the best effects. The second claims that the rights of the deceased and the family are negative rights, limited to a veto.

Consider first the argument from best effects. It is possible that, when all costs and benefits are taken into account, giving individuals and families each a veto over donation would lead to the greatest net benefit. The various costs and benefits would include the effects on the supply of organs and tissues on those who receive them; the effects on families and the deceased (which might be zero, if the deceased have no posthumous interests), and broader effects on medical care and perceptions of it.

How might the arguments go? Consider the familiar, if paradoxical, claim that, if the wishes of the deceased to donate were allowed to override the opposition of their families, this would cause a public scandal that would, in turn, cause a decline in the supply of organs and tissues. Here is one explanation of this claim. Some people fear that if they became seriously ill, they would receive less thorough treatment if they were donors than if they were non-donors because doctors want their organs. This fear-which need not be well founded to have an effect-would increase if families were known to be overridden. People look to their families to protect them when they cannot protect themselves. Publicly overriding families would make people feel more vulnerable to doctors skimping on their treatment and so more reluctant to donate. Hence the supply of organs will decline. This claim could be part of what is needed to show that giving families a veto would have the best effects. Another part would require showing that giving the individual a veto would also have the best effects. Perhaps there would be very bad effects if 
individual refusals could be overridden, because, for instance, this would cause great strain on family relations among the living or because it would harm significant posthumous interests.

If the double veto had better effects than any of the other ways of distributing power between individuals and families, there would then be a rationale for the current position that was in no way incoherent. Is the best effects argument a good one? Its success depends on whether it is true that giving the individual and the family each a veto would produce the greatest net benefit. Showing that requires the tricky double task of establishing what the effects of various policies would be, and then evaluating them. The argument also relies on the best effects being decisive, and so on there being no further considerations, such as the rights of the individual, that would be of greater moral force. It is to rights that I now turn.

The second way to produce a coherent position makes use of the idea of rights, and understanding it requires a very brief discussion of rights in general. Rights are used more or less loosely in moral arguments. The claim here is not that the following points about rights show the only correct use, but rather that they allow a case to be made for the double veto. First, rights are here understood in the philosophically commonplace sense of being moral claims of decisive or near decisive force. Thus people's rights cannot be overridden whenever this would produce better consequences. This is why, to take a very familiar case in moral philosophy, the right not to be murdered makes it morally wrong to cut up a healthy friendless person in order to use his organs to save five people, even if five deaths are worse than one death. ${ }^{13}$ This makes rights very demanding, and so we need some good reason to think, in any given case, that someone has a right. Second, rights are here taken as moral rights rather than legal rights, and the point of talking about what rights individuals or families have is to find out what the law ought to be, not what it is. Third, rights have correlative duties. So my property right in my pen imposes a duty on you not to steal it. Fourth, we can distinguish negative and positive rights. Negative rights are rights against interference; positive rights are rights to assistance.

Suppose that the individual had a negative right to withhold her organs and tissues, but no positive right to donate. That is, all people, including surgeons, would be under a duty not to make use of her body if she refused; but her consent would not put them under a duty to make use. And suppose, similarly, that the family had a negative right to withhold, but no positive right to donate so that, as in the case of the individual, people are under a duty to do what they say when they withhold but not when they offer to donate. If both individual and family have a negative right, then we have the makings of a coherent basis for the current position, the double veto. It is, however, only the makings, because we have yet to see why we should think that either the individual or the family has the negative right to withhold at all and, if so, why one or the other does not also have the positive right to donate with binding force.

There is no space here for any full argument. Briefly and dogmatically, it seems unlikely that the family has any relevant negative or a positive right. True though it might be that overriding the family would cause distress, for instance, the possibility of distress is not the basis for a right in the demanding sense described above. It does not infringe on any right of the family to tell them that their loved one has died even if this causes them distress. So I do not accept the negative rights defence of the double veto as just outlined. It is possible, however, to modify this defence. There are moral reasons, which are neither based on, nor have the force of, rights. Suppose the family has no right to veto or donate.
There could none the less be reasons, such as reducing distress or avoiding bad publicity, to do what the family wants. Suppose these reasons are strong, but also suppose that the individual has a negative right of veto. Then we could say this for the current position: do what the family says except where it conflicts with the negative right of veto of the individual. That amounts to the double veto without relying on the claim that the family has a right to veto, although of course the defence only works if the reasons really are strong ones.

Let us now consider the individual's possible rights. We are here talking about the rights of someone who is dead. Can there be posthumous rights? Well, if not, then the rights attempt to rescue the current position fails, since it includes the (posthumous) right to refuse donation. Let us assume there can be posthumous rights. Moreover, since the focus of this paper is on coherence, let us assume that the individual has a negative right of veto. The question of coherence is: how could one have this negative right without also having the right to override one's family? Some claim that consistency requires that if there is a right not to donate, then there is a right to donate without the family veto. The rest of this paper shows this consistency claim to be false. ${ }^{14}$

Some of those who criticise the family veto argue that the autonomy rights of the individual preclude it. They argue that the predeath wishes of the deceased should have the same binding force that an advance directive has when patients are alive but incompetent to make choices. ${ }^{15}$ This, however, is all far too quick. First, the fact that people are dead must make some difference to the strength and nature of their claims when compared with incompetent living patients, so the analogy is, at least, imperfect. Second, the idea of autonomy is too broad to be much help. There are many different sources of autonomy. For instance, the negative right might be a right against "trespass", that is, against unconsented to intrusion into the body (Thomson, ${ }^{13}$ ch 8 ). Removal of organs is intrusion, and unconsented to, it is trespass. It is not trespass if no removal occurs, even if the individual wants it, so a right against trespass permits a family veto.

There is more to autonomy than protection against trespass but-and this is a third point-whatever else there is does not support a positive right to donate that imposes a binding duty on intensivists and transplant teams to accept the offer. Whatever its significance for autonomy, the right to offer does not ordinarily include the right to have an offer accepted. Suppose the intensivists and transplant teams do not retrieve someone's organs on the grounds that they are unsuitable for transplant. Suppose they turn down the organs on the ground that the family objects and they fear the public reaction if they override the family. Neither seems to violate a duty to the individual deceased. Since rights are correlative to duties, the deceased could only have a positive right to have her offer accepted if others had a duty to the deceased to accept the right. They do not have the duty. So the individual does not have a positive right. Hence it is quite coherent to say that an individual has a negative right of veto but no positive right to have organs and tissues taken after consenting. That said, there may be reasons to honour the deceased's offer, such as promoting her autonomy, even if these do not amount to a right. These reasons might be overriding, so the double veto is not vindicated by the rights argument. However, the double veto is none the less coherent, which is all this paper aims to show.

\section{CONCLUSION}

The current position on the deceased's consent and the family's consent to organ and tissue donation from the dead is a double veto-each has the power to withhold and override the other's desire to donate. This paper has raised, 
and to some extent answered, questions about the coherence of the double veto. It can be coherently defended in two ways: if it has the best effects and if the deceased has only negative rights of veto. Whether the double veto has better effects than other policies requires empirical investigation, not undertaken here. As for rights, the paper has shown it is entirely possible that individuals have a negative right of veto but no positive right to compel acceptance of their offers. Thus if intensivists and transplant teams turn down the deceased's offer, they do not thereby violate the deceased's right. This leaves it open whether non-rights based reasonssuch as avoiding bad publicity, avoiding distress, or promoting the deceased's autonomy-require intensivists and transplant teams to turn down or accept the deceased's offer. This is, however, beyond the scope of this paper. So too is the more radical position that neither individuals nor family should decide, but that bodies should instead be conscripted..$^{16}$ The current position may or may not be wrong, but it is at least coherent.

\section{ACKNOWLEDGEMENTS}

My thanks to Paula Boddington, David Price, Stephen Streat, and an audience at the University of Auckland.

\section{REFERENCES}

1 Ministry of Health. Review of the regulation of human tissue and tissue-based therapies: discussion document. Wellington: Ministry of Health, 2004:64.
2 Price D. From Cosmos and Damian to Van Velzen: the human tissue saga continues. Med Law Rev 2003;11:1-47 at 9.

3 Veatch R. Transplantation ethics. Washington DC: Georgetown University Press, 2000:148-9.

4 Kamm F. Morality, mortality vol 1. New York: Oxford University Press, 1993:205-12, 217-21

5 Price D. Legal and ethical aspects of organ transplantation. Cambridge: Cambridge University Press, 2000:ch 3.

6 Feinberg J. Harm to others. New York: Oxford University Press, 1984.

7 Wilkinson TM. Last rights: the ethics of research on the dead. $J$ Appl Philos 2002;19:31-41.

8 British Medical Association. Human tissue \& organs-presumed consent for organ donation. http://www.bma.org.uk/ap.nsf/Content/ Humantissueorganspresumed? OpenDocument\&Highlight = 2, presumed, consent (accessed 5 Jan 2005)

9 Boddington P. Organ donation after death-should I decide, or should my family? J Appl Philos 1998;15:69-81 at 70.

10 Streat $\mathbf{S}$. Moral assumptions and the process of organ donation in the intensive care unit. Crit Care 2004;8:382-8.

11 Australian National Health and Medical Research Council. Donating organs after death: ethical issues. Canberra: The Australian Government Publishing Service, 1997:1.

12 Chan HM. Sharing death and dying: advance directives, autonomy and the family. Bioethics 2004; 18:87-103.

13 Thomson JJ. The realm of rights. Cambridge MA: Harvard University Press, 1990: 135 .

14 Lamb D. Organ transplantation and ethics. London: Routledge, 1990:145.

15 May T, Aulisio M, de Vita M. Patients, families, and organ donation: who should decide? Milbank Q 2000;78:323-36 at 331-3.

16 Harris J. Organ procurement: dead interests, living needs: cadaver organs should be automatically available. J Med Ethics 2003;29:130-4. 